\title{
A NEW GENERATION OF HYDROGEN PEROXIDE AS A FUNGICIDAL DISINFECTANT IN RABBIT HOUSES
}

\author{
Amgad A. Moawad "and S.A. El-Midany "* \\ "Department of Microbiology, Faculty of Veterinary Medicine. \\ Kafr EL-Sheikh University. Egypt \\ "Department of Hygiene and Preventive Medicine, Fact. Vet. Med., \\ Kafr El-Sheikh University .Egypt
}

\begin{abstract}
The experiments were performed on rabbits suffering from dermatophytosis caused by Trichophyton mentagrophytes, also Microsporum canis were found at percentages of $55.7 \%$ and $20 \%$ respectively. Moreover, Aspergillus niger, Aspergillus candidus, Fusarium, Alternaria spp, Penicillium spp and Cladosporium spp, Curvularia spp Mucor spp. and Rhodotorula spp were isolated from fur of rabbits. The isolates from rabbit's samples were isolated from the air and for surface of rabbit houses at Gharbia Governorate from December 2007 till February 2008. Surface disinfection and decontamination provide temporary amelioration against microbial colonization. Disinfected surfaces eventually become contaminated, thus, mitigating the benefit of the initial disinfection. We describe here ionized hydrogen peroxide (IHP) disinfectant technology designed to provide longlasting sanitization and disinfection to air and treated surfaces as evaluated on hard surfaces after repeated environmental insults. The results of this study showed that IHP application at a rate of $1 \mathrm{~mL} / \mathrm{m} 3$ had high fungicidal activity in addition to being a fast acting disinfectant. We found IHP to be effective as aerial fungicide (inactivate fungi within 5 minutes), while the spores deposition on surfaces were inactivated after 5 daily uses.
\end{abstract}




\section{INTRODUCTION}

Ringworm is an infectious disease of animals caused by different species of keratinophilic fungi. It is a major public and veterinary health problem reported from different parts of the world and causes great economic losses (Calderone, 1989). In rabbits, dermatophytosis is most often caused by Trichophyton mentagrophytes and Microsporum canis (Chermette et al., 2008; Pier et al., 1994 and Torres-Rodriguez et al., 1992). Dermatophytosis is common in the rabbit. T. mentagrophytes is the most common dermatophytes isolated from rabbits (Cabanes et al., 1997; DonneUy et al., 2000 and Franklin et al., 1991). Infection with $M$. canis is occasionally reported and individual cases of M. gypseum, although rare, are infrequently described (DonneUy et al., 2000; Simaljakova Buchvald and Olexova, 1989 and Zaror and Casas, 1988). Infection with 3 other species, M. audouinii, T. verrucosum, and T. schoenleinii are extremely rare, and previous reports of these infections in rabbits were most likely due to misidentification (Bergdall and Dysko, 1994).Young rabbits are most susceptible to infection. Lesions usually arise on or about the head, and are characterized by patchy alopecia, broken hairs, erythema, and yellowish crusting (Scott et al., 1995). The lesions are pruritic and may spread secondarily to the paws, especially the toenail beds, and to other areas of the body (Bergdall and Dysko, 1994). Rabbits can be asymptomatic carriers of $T$. mentagrophytes. Franklin et al., 1991 found 5 out of 8 rabbits that cultured positive for T. mentagrophytes had no histological evidence of infection while Balsari et al., 1981 isolated T. mentagrophytes from the hair coat and skin of up to $36 \%$ of clinically normal rabbits. Dermatophytosis in rabbits is usually self-limiting, although factors such as reduction of stress and improved 
environmental conditions are important considerations in lesion regression (Franklin et al., 1991). Fungal spores constitute a significant fraction of airborne bioparticles (Adhikari et al., 2004; Ebner and Haselwandter, 1992 and Takahasi, 1997). inhaled air, containing a large number of fungal spores, probably the largest constituent of microorganisms in bioaerosol, ranging from 3 to $30 \mu \mathrm{m}$ in size (Stetzenbach, 1998). Fungal spores of $>10 \mu \mathrm{m}$ sizes are deposited in the nasopharynx and are associated with nasal and ocular symptoms (Luo, 1991). Spores $<10 \mu \mathrm{m}$ size, especially those of $<6 \mu \mathrm{m}$ size, can be transported to the lower airways and lungs where allergic reactions (Pepys, 1965). In relation to the fungal air spreading, it is depending on many factors such as relative humidity (RH), above $70 \%$ (Burge et al. ,1995), temperature $\left(>25^{\circ} \mathrm{C}\right.$ ) and overcrowding in cages. Particularly, among fungi, it's important to consider the activity of the typical environmental ones, such as Aspergillus, Penicillium, Alternaria, Cladosporium (potential pathogens or saprophytic species) that are able to produce a great number of spores which are released in the environment (air, bedding, etc.) and that could cause respiratory diseases. It has been reported that animals housed in close proximity to each other for long periods and the presence of infected debris in buildings account for both the higher incidence and the greater infection rate in winter (Adhikari et al., 2004; Radostits et al. 1997). T. verrucosum, T. mentagrophytes and Microsporum species were the most common fungi isolated from cases of animal dermatophytosis (AbouGabal et al. 1976; Al-Ani et al.1995). Measures to control and prevent dermatophytosis include sanitation, hygienic measures and treatments (Lund and De Boer, 2008). In a program for eradication of ringworm from herds, cleaning and disinfection is recommended as additional measures and contributing to reduction in the level of environmental 
contamination. Improved hygiene shortens the time needed to achieve the goal of animals without signs of ringworm and the long-term goal of eradication of ringworm from the herd (Lund and De Boer, 2008). Rough surfaces, high organic soiling, low temperatures and several other involved circumstances are strongly limiting factors in disinfection. In these tests it is verified whether, after a normal period of use, germs were killed(Bohm, 1998). The antifungal agent selected was hydrogen peroxide $\left(\mathrm{H}_{2} \mathrm{O}_{2}\right)$ has been a commercial product since the 1880 's. $\mathrm{H}_{2} \mathrm{O}_{2}$ was considered environmentally friendly, because it was rapidly degraded into the innocuous products water and oxygen (Juven and Pierson 1996). Although pure solutions were generally stable, most contain stabilizers to prevent decomposition. $\mathrm{H}_{2} \mathrm{O}_{2}$ demonstrated broad-spectrum efficacy against viruses, bacteria, yeasts, and bacterial spores (Block, 1991; Jeffrey, 1997). The aims of the present study were to isolate and identify the causative fungi of ringworm in rabbits and rabbit houses, and to study the efficacy of ionized $\mathrm{H}_{2} \mathrm{O}_{2}$ in aerial fungal disinfection.

\section{MATERIAL AND METHODS}

\section{A. Material:}

\section{1- Aeromycological samples:}

Air samples were collected from the five rabbit houses present in different sites at Gharbia Governorate December 2007 to February 2008. Eight test points in the building, three times a day (at 7.00 h, $14.00 \mathrm{~h}$ and $19.00 \mathrm{~h}$ ), throughout the three months of winter over 10-day periods. Fungal contamination of air analyzed by gravity plates (Settle plates) method was used. The test points were chosen according to the scheme of Baykov and Tyrawska (1991). After collection, Petri dishes are incubated and the colonies are counted and identified as colony forming units (CFUs) per $1 \mathrm{~m}^{2}$ of the air. 


\section{2- Surface Samples:}

The surfaces were divided into squares of $10 \times 10 \mathrm{~cm}^{2}$ with masking tape. Sampling was performed with swabs before and after disinfection $1 \mathrm{~h}$ daily until six days. It was repeated after one day, seven days and 14 days to evaluate whether the residual effect of the disinfectant was detected. Swab cultures of environmental surfaces obtained immediately were plated directly.

\section{3- Rabbits:}

A total of 80 rabbits of New Zealand, California and Hybrids rabbits. Those rabbits were selected from 5 farms at Gharbia governorate. They were housed in galvanized wire mesh cages in batteries on flat-deck.

There was a history of loss of fur and skin lesions on different areas of rabbit's body. All rabbits were close to 2 months old (after weaning). With an average weight $900 \mathrm{gm}$. The prevalence of ringworm infection varied from farm to farm with a range of 5 to $90 \%$.

The hair and skin scrapings were collected from clinically suspected ring worm lesions of rabbits. Also, hair samples were collected from apparently healthy rabbits.

\section{4- Disinfectant:}

The system is composed of a machine (Nocospray) and a solution (Nocolyse). Disinfectants (Airel, France), 6\% $\mathrm{H}_{2} \mathrm{O}_{2}$, 40 part per million of silver nitrate in a sable aqueous solution of 0.1 micro-siemens conductivity water and a surfactant designed for the disinfection of air and environmental surfaces.

Nocospray was a powerful turbine with a venture system. It efficiently provides the three criteria to ionize hydrogen peroxide; an outflow speed of 80 meters per second, particle size of 2-7 microns and a temperature of $37^{\circ} \mathrm{C}$. The machine was portable and weighs $5.8 \mathrm{Kg}$. Its timer was expressed in terms of cubic meters to provide a dose of $1 \mathrm{ml}$. of solution for 1 cubic meter of space. 


\section{5- Recording of meteorological parameters:}

Temperature and relative humidity were recorded in each place during sampling time using a Hygrothermometer.

6- Media and stains:

The media were as follows:

6.1. Sabouraud's dextrose agar with chloramphenicol and actidione: (Monica Cheesbrough, 1993).

Both chloramphenicol $(0.25 \mathrm{~g}$ in $10 \mathrm{ml} 95 \%$ ethanol)and cycloheximide ( $0.5 \mathrm{~g}$ in $10 \mathrm{ml}$ of acetone) were added to the sterile medium (1liter). This medium was used for isolation and characterization of dermatophytes and cycloheximide- resistant keratinophilic fungi but addition was not for the aerogenic fungi.

6.2. Sabouraud's dextrose agar enriched with thiamine: (Rebell and Taplin, 1970).

Thiamine $(0.001 \mathrm{~g})$ was added to the sterile medium (1liter). This medium was used for subculture of some species of dermatophytes.

6.3. Sabouraud's dextrose agar without antibiotics: (Jaroslave and Millos, 1969).

This medium was used for characterization of keratinophilic fungi.

6.4. Sabouraud's dextrose broth with chloramphenicol: (Monica Cheesbrough, 1993).

Chloramphenicol $(0.25 \mathrm{~g}$ in $10 \mathrm{ml} 95 \%$ ethanol) was added to the sterile medium (1liter). This medium was used for isolation of fungi present on surfaces.

6.5. Lactophenol cotton blue: (Monica Cheesbrough, 1993). 


\section{B. Methods:}

\section{1- Evaluation of disinfectant on fungi in the air:}

The level of contamination of the room atmosphere was estimated by six 1-min air samples using Sabouraud's dextrose agar with chloramphenicol $\left(10 \mathrm{~cm}\right.$ diam) plates. After incubation for $7-10$ days at $27^{\circ} \mathrm{C}$. The results were expressed as Colony Forming Units (CFU) per cubic meter of air $\left(\mathrm{CFU} / \mathrm{m}^{3}\right)$. The volume of area was calculated in square meters. Then the timer was adjusted corresponding to that area. Nocospray machine was placed at one corner for a distance of 25 meters. The treatment was repeated daily for another 6 days to complete 7 applications.

\section{2- Evaluation of disinfectant on fungi deposited on surfaces:}

Swabs from surfaces of rabbit houses were taken before and after 60 minutes from disinfection. (Bartels et al., 2008) .The swabs were returned to laboratory for incubation at $26{ }^{\circ} \mathrm{C}$ for $2-6$ weeks and examined daily for the colony character. The results are expressed as Colony Forming Units per plate (CFU/plate).

\section{3- Dermatophyte in rabbits:}

The suspected untreated lesions were first rubbed with a cotton swab impregnated with $70 \%$ ethyl alcohol to remove surface adhering organisms. Skin scales were collected by scraping of the margin of the lesion using a sterile scalpel blade into sterile Petri dish. Hairs were collected by removing dull broken hairs from the margin of the lesion using sterile tweezers as described (Cheesbrough 1992 and Szilli and Kohlami, 1981). Each sample collected was divided into two portions. One portion was used for direct microscopic examination. The second portion was cultured on mycobiotic agar (DIFCO), incubated at $28{ }^{\circ} \mathrm{C}$ for $2-6$ weeks and examined for the colony character. 


\section{4- Fungal identification:}

Identification of the pathogenic fungi by macroscopic and microscopic examination was performed and included time of appearance of the growth, colony morphology, color, shape, size and colony reverse side morphology. Microscopic examination for positive fungi cultures was done using the lactophenol cotton blue wet mount method (Frey et al. 1979 and Ajello et al., 1976). The slide culture technique was used when the lactophenol cotton blue wet mount failed to show the manner in which conidia are formed and attached to the conidiophores (Al-Doory 1980).

\section{RESULTS AND DISCUSSION}

In Egypt, ringworm infection is commonly associated with rabbits occurred throughout the year with a higher prevalence during winter time due to high humidity which facilitates the growth of spores and increases the susceptibility of animals to infection (Nooruddin and Singh 1987). Trichophyton mentagrophytes is the fungal species most commonly isolated with prevalence rate of $55.7 \%$ while Microsporum canis is $20 \%$ (Table 1). This is in agreement with Sarkisov and Nikiforov (1981) who found that Trichophyton mentagrophytes was the most common dermatophytes causing dermatitis for rabbit followed by Microsporum spp. While, Aspergillus, Penicillium, Alternaria, Curvularia, Fusarium, Mucor and Cladosporium were isolated from rabbits affected with dermatitis and from rabbit houses. A total of 9 fungal genera and a lot of species were recorded at an average temperature of $15 \mathrm{C}$ and average of $85 \% \mathrm{RH}$. Other fungi were Cladosporium, Curvularia, Fusarium, Mucor and Rhodotorula (Table 2). These findings were similar to those of (Pitt, 1994) who also found that Aspergillus, Penicillium, Alternaria and Mucorales 
are typical environmental fungi that are able to produce a high number of spores that are released in the air and could cause respiratory diseases. The high fungal count established the fact that temperature and relative humidity are two important factors for fungal spore generation, release and dispersal; particularly in indoor environments (Herrero and Zaldivar, 1997 and Larsen and Frisvad, 1994). Mean recovery of fungi with gravity plates was $1.07+0.03 \mathrm{CFU} / \mathrm{m} 2(\log 1 \mathrm{o}+$ standard error). Gravity plates may serve as a low-cost indicator of the presence and approximate concentration of fungi and may be useful in providing additional information, such as distribution patterns, unattainable with the more costly forcedair flow samplers as demonstrated by Buttner and Linda Stetzenbach, (1991).

$\mathrm{H}_{2} \mathrm{O}_{2}$ activity is significantly increased in the gaseous phase. $\mathrm{H}_{2} \mathrm{O}_{2}$ acts as an oxidant by producing hydroxyl free radicals $(\mathrm{OH})$ which attack essential cell components, including lipids, proteins, and DNA. It has been proposed that exposed sulfhydryl groups and double bonds are particularly targeted (Block, 1991).The mechanism of the antimicrobial action of silver ions is closely related to their interaction with thiol (sulfydryl, SH) groups(Belly and Kydd,1982;Bragg and Rannie, 1974; Furr et al., 1994), although other target sites remain a possibility(Richards, 1981; Thurmann and Gerba, 1988).

We tested whether one application of IHP was sufficient to eliminate fungi. Air samplings revealed a fungal contamination too high to be counted .Surprisingly, we found that none of the fungi survived after one application (all fungi inactivated in 5 minutes). On the other hand, floors and other surfaces become contaminated by settling of airborne fungi. Daily application of ionized hydrogen peroxide for 6 days was able to 
inactivate all fungi to undetectable levels on the surfaces. Beside treatment of rabbits reduce existent infection. The count reductions (disinfection percentages) were $93.82 \%, 99.64 \%, 99.96 \%, 99.98 \%$ and $100 \%$ after $1^{\text {st }}$, $2^{\text {nd }}, 3^{\text {rd }}, 4$ th and $5^{\text {th }}$ applications respectively (Table 3 ). This result is in agreement with similar observations reported on meticillin-resistant Staphylococcus aureus (MRSA) by (Hardy et al.2007) using hydrogen peroxide vapour alone was very effective in eliminating this bacteria from air, Moreover addition of silver was more effective in air but not sufficient for contaminated surfaces (Bartels et al., 2008). Ionization of hydrogen peroxide beside silver was effective in surface disinfection. After disinfection, no growth of fungi was found during the 7 days of follow-up. The residual antimicrobial activity of IHP is due to silver as described by Brady et al., (2002). Recent studies demonstrated that undiluted bleach and $1 \%$ formalin were able to kill all dermatophytes arthroconidia in the environment (Chermette et al., 2008). However, because of toxic properties, both drugs are not recommended for use in households. Bleach at 1:10 dilution and enilconazole solution $(0.2 \%)$ was also proved to be active (Rycroft and Mclay, 1991). All other disinfectants demonstrated poor efficacy. An enilconazole smoke fumigant formulation is available in most European countries (Chermette et al., 2008). The mechanism by which hydrogen peroxide kills spores is not known, while killing of vegetative bacteria (Ananthaswamy and Eisenstark, 1977; Imlay and Linn, 1988) and fungi (Frankenberg et al., 1993) is known to involve DNA damage. Higher concentrations of $\mathrm{H}_{2} \mathrm{O}_{2}$ (10 to 30\%) and longer contact times are required for sporicidal activity (Russell, 1991), although this activity is significantly increased in the gaseous phase. In most cases, the problems of $\mathrm{H}_{2} \mathrm{O}_{2}$ usage are, first the corrosivity of it is due to dissolved oxygen which is a natural decomposition product of 
$\mathrm{H}_{2} \mathrm{O}_{2}$. Second, $\mathrm{H}_{2} \mathrm{O}_{2}$ decomposition that include: increasing temperature; increasing $\mathrm{pH}$; increasing contamination; and to a lesser degree, exposure to ultraviolet light. Third, limit exposure of the product to environmental stresses such as heat, sunlight or dust. And fourth, control the degree of contamination. $\mathrm{H}_{2} \mathrm{O}_{2}$ is subjected to two stages of improvement. The first is the addition of silver ions as silver nitrate at $500 \mathrm{ppm}$ with a reduction of hydrogen peroxide concentration to $50 \%$ (Alasari et al., 1992). To activate this form, a room temperature around $50^{\circ} \mathrm{C}$ is required. The mechanism of the antimicrobial action of silver ions is closely related to their interaction with thiol (sulfydryl, SH) groups (Belly and Kydd, 1982;

Bragg and Rannie, 1974; Furr et al., 1994), although other target sites remain a possibility (Richards, 1981; Thurmann and Gerba, 1988). Silver appears to kill micro-organisms instantly, by blocking the respiratory enzyme system as well as altering microbe DNA and the cell wall (Imlay and Linn, 1987; Ovington, 2004; Silver, 2003). The main merit of the first stage being an introduction to the second revolutionary stage which was simply to ionize Hydrogen peroxide and silver together with a surfactant. By this, Nocospray-Nocolyse system was invented.In conclusion, the ionized hydrogen peroxide tested in this study proved to be fastacting fungicide with high safety.

Table (1): Fungi isolated from fur of rabbits affected with dermatitis.

\begin{tabular}{|l||c||c|}
\hline \multicolumn{1}{|c||}{ Isolated fungi } & No. of isolates & \% \\
\hline \hline Trichophyton mentagrophytes & 39 & 55.7 \\
\hline Microsporum canis & 14 & 20 \\
\hline Microsporum gypsum & 6 & 8.5 \\
\hline Aspergillus candidus & 4 & 5.7 \\
\hline Alternaria spp & 4 & 5.7 \\
\hline Penicillium spp & 2 & 2.8 \\
\hline Cladosporium spp & 1 & 1.4 \\
\hline & $\mathbf{7 0}$ & \\
\hline
\end{tabular}


Table (2): Fungi isolated from rabbit house.

\begin{tabular}{||l||c||c||}
\hline \multicolumn{1}{|c||}{ Isolated fungi } & No: of isolates & \% \\
\hline \hline Trichophyton mentagrophytes & 16 & 00 \\
\hline Microsporum canis & 10 & 00 \\
\hline Microsporum gypsum & 08 & 00 \\
\hline Aspergillus niger & 76 & 00 \\
\hline Penicillium spp & 67 & 00 \\
\hline Curvularia spp & 01 & 00 \\
\hline Fusarium spp & 02 & 00 \\
\hline Cladosporium spp & 01 & 00 \\
\hline Mucor spp & 36 & 00 \\
\hline Rhodotorula spp & 01 & 00 \\
\hline Disinfection percentage\% & 0 & 100 \\
\hline
\end{tabular}

Table (3): Fungicidal activity of ionized hydrogen peroxide (NOCOLYSE) ${ }^{\circledR}$ on surfaces of rabbit houses.

\begin{tabular}{|c|c|c|c|c|c|c|c|c|}
\hline \multirow[b]{2}{*}{ Isolated fungi } & \multirow[b]{2}{*}{$\begin{array}{c}\text { Before } \\
\text { treatment }\end{array}$} & \multicolumn{7}{|c|}{ After disinfection } \\
\hline & & $\begin{array}{c}\text { Day } \\
1\end{array}$ & $\begin{array}{c}\text { Day } \\
2\end{array}$ & $\begin{array}{c}\text { Day } \\
3\end{array}$ & $\begin{array}{c}\text { Day } \\
4\end{array}$ & $\begin{array}{c}\text { Day } \\
5\end{array}$ & $\begin{array}{c}\text { Day } \\
6\end{array}$ & $\begin{array}{c}\text { Day } \\
7\end{array}$ \\
\hline $\begin{array}{l}\text { Trichophyton } \\
\text { mentagrophytes }\end{array}$ & $62 \times 10^{3}$ & $37 \times 10^{2}$ & $23 \times 10^{1}$ & 18 & 6 & 3 & 0 & 0 \\
\hline Microsporum canis & $24 \times 10^{3}$ & $14 \times 10^{2}$ & $9 \times 10^{1}$ & 7 & 2 & 1 & 0 & 0 \\
\hline $\begin{array}{l}\text { Microsporum } \\
\text { gypseum }\end{array}$ & $11 \times 10^{3}$ & $6 \times 10^{2}$ & $5 \times 10^{1}$ & 4 & 3 & 1 & 0 & 0 \\
\hline Aspergillus niger & $06 \times 10^{3}$ & $4 \times 10^{2}$ & $2 \times 10^{1}$ & 2 & 1 & 1 & 0 & 0 \\
\hline Penicillium spp & $07 \times 10^{3}$ & $3 \times 10^{2}$ & $3 \times 10^{1}$ & 2 & 1 & 0 & 0 & 0 \\
\hline Curvularia spp & $01 \times 10^{2}$ & $4 \times 10^{1}$ & 3 & 2 & 1 & 1 & 0 & 0 \\
\hline Fusarium spp & $02 \times 10^{1}$ & $1 \times 10^{1}$ & 0 & 0 & 0 & 0 & 0 & 0 \\
\hline Cladosporium spp & $01 \times 10^{1}$ & $\overline{0}$ & 0 & 0 & 0 & 0 & 0 & 0 \\
\hline Mucor spp & $06 \times 10^{1}$ & 0 & 0 & 0 & 0 & 0 & 0 & 0 \\
\hline Rhodotorula spp & $02 \times 10^{1}$ & $\overline{0}$ & 0 & 0 & 0 & 0 & 0 & 0 \\
\hline TOTAL & $110.21 \times 103$ & $68.1 \times 102$ & $3.93 \times 102$ & $3.5 \times 10^{1}$ & $1.4 \times 10^{1}$ & $0.7 \times 10^{1}$ & $\overline{0}$ & 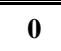 \\
\hline $\begin{array}{l}\text { Inactivation } \\
\text { percentage }(\%)\end{array}$ & - & 93.82 & 99.64 & 99.96 & 99.98 & 99.99 & 100 & 100 \\
\hline
\end{tabular}




\section{REFERENCES}

- Abou-Gabal, M.; Abdel-Galil, G.; Abdel-Nor, E.; Abdel-Nor, E.; Abdel-Rehim, D. (1976): Animal ringworm in Upper Egypt. Sabouraudia 14: 33-36.

- Adhikari, A; Sen,M.M.; Gupta-Bhattacharya ,S. and Chanda, S. (2004): Volumetric assessment of airborne fungi in two sections of a rural indoor dairy cattle shed. Environment International 29 (8):10711078

- Ajello, L.; Georg, L. and Kaplan, W. (1976): Laboratory manual for medical mycology, Pub. Hlth. Service, C.D.C. Atlanta, Georgia, USA.

- Al-Ani, F. K.; Al-Bassam, L. S. and Al-Salhi, K. A. (1995): Epidemiological study of dermatomycosis due to Trichophyton schoenleinii in camels in Iraq. Bull. Anim. Hlth. Prod. Afr. 43: 87-92

- Alasari,A.; Roques, C. and Michel, G. (1992): Bactericidal properties of peracetic acid and hydrogen peroxide, alone and in combination, and chlorine and formaldehyde against bacterial water strains. Canadian Journal of Microbiology 32: 635-642.

- Al-Doory, Y. (1980): Laboratory Medical Mycology. Lea and Febiger, Philadelphia: 12-122.

- Ananthaswamy, H.N. and Eisenstark, A., (1977): Repair of hydrogen peroxide-induced single strand breaks in Escherichia coli deoxyribonucleic acid. J. Bacteriol. 130: 187-191

- Balsari, A.; Bianchi, C.; Cocilovo, A. et al (1981): Dermatophytes in clinically healthy laboratory animals. Lab Anim 15:75-77. 
- Bartels,M.D.; Kristoffersen,K.;Slotsbjerg,T.;Rohde,S.M.; Lundgren, B.and Westh,H.(2008): Environmental meticillin-resistant Staphylococcus aureus (MRSA) disinfection using dry-mist-generated hydrogen peroxide, J Hosp Infect 70 : 35-41

- Baykov, B. and Tyrawska, D. (1991): Ecological Studies on Anthropogenic Ecosystems for Production of Poultry Meat and Eggs. Institute of Ecology, Publishing Office, Warsaw.

- Belly, R.T. and Kydd, G.C. (1982): Silver resistance in microorganisms. Dev Ind Microbiol. 23:567-577.

- Bergdall, V.I.and Dysko, R.C.(1994): Metabolic, traumatic, mycotic and miscellaneous diseases, in Manning PJ, Ringler DH, Newcomer CE (eds): The Biology of the Laboratory Rabbit (ed 2). San Diego, CA, Academic Press, Inc.

- Block, S.S. (1991): Peroxygen compounds. In: Block SS., editor. Disinfection, sterilization, and preservation. 4th ed. Philadelphia, Pa: Lea \& Febiger. : 167-181.

- Bohm, R. (1998): Disinfection and hygiene in the veterinary field and disinfection of animal houses and transport vehicles International Biodeterioration \& Biodegradation 41: 217-224.

- Brady, M. J.; Catherine Lisay, M.; Yurkovetskiy, A.V.; Sawan, S. P. and Massachusetts, T. (2002): Persistent silver disinfectant for the environmental control of pathogenic bacteria .Am J Infect Control, 31:208-14.

- Bragg, P.D. and Rannie, D.J. (1974): The effect of silver ions on the respiratory chain of Escherichia coli. Can J Microbiol. 20:883-889. 
- Burge, H.; Chew, G.; Muilenberg, M. and Gold, D. (1995): Role of fungi in-house dust ecosystems. Journal of Allergy and Clinical Immunology 95: 167.

- Buttner, M.P. and Linda Stetzenbach, D. (1991): Evaluation of four aerobiological sampling methods for the retrieval of aerosolized Pseudomonas syringae. Applied and environmental microbiology, 57 (4):1268-1270.

- Cabanes, F.J.; Abarca, M.L. and Bragulat, M.R. (1997): Dermatophytes isolated from domestic animals in Barcelona, Spain. Mycopathologia 137:107-113.

- Calderone, R.A. (1989): Immunoregulation of dermatophytosis. Crit. Rev. Microbiol. 16: 339-368

- Cheesbrough, M. (1992): Medical Laboratory Manual for Tropical Countries. Volume 2. Tropical Health Technology, ButterworthHeinemann, Great Britain: 371-385

- Chermette, R.; Ferreiro, L. and Guillot, J. (2008): Dermatophytoses in Animals. Mycopathologia 166:385-405.

- DonneUy, T. M. ;Elizabeth Rush, M. and Petra Lackneg, A. (2000): Ringworm in Small Exotic Pets.82th Seminars in Avian and Exotic Pet Medicine, 9: 82-93.

- Ebner, M.R. and Haselwandter, K. (1992): Indoor and outdoor incidence of airborne fungal allergens at low and high-altitude alpine environments. Mycol. Res. 96: 117-124. 
- Frankenberg,D.; Frankenberg-Schwagner,M.and Harbich,R.(1993): Mechanisms of oxygen radiosensitization in irradiated yeast. I. DNA double-strand breakage. Int. J. Radiat. Biol. 64: 511-521.

- Franklin,C.L.; Gibson, S.V.; Caffrey, C.J.; Drugan, C.; Oppenheim, B.A.; Gao, F. and Havkey, P.M. (1991): Treatment of Trichophyton mentagrophytes infection in rabbits. J Am Vet MedAssoc 198:16251630.

- Frey, D.; Oldfield, R.J. and Bridger, R.C. (1979): A colour atlas of pathogenic fungi. Wolje Medical publication Ltd, Holland.

- Furr, J.R.; Russell, A.D.; Turner, T.D. and Andrews, A. (1994): Antibacterial activity of Actisorb Plus, Actisorb and silver nitrate. J Hosp Infect. 27:201-208.

- Hardy, K.J.; Gossain S. and Henderson, N. et al. (2007): Rapid recontamination with MRSA of the environment of an intensive care unit after decontamination with hydrogen peroxide vapour, $J$ Hosp Infect $66: 360-368$.

- Herrero, B. and Zaldivar, P. (1997): Effects of meteorological factors on the levels of Alternaria and Cladosporium spores in the atmosphere of Palencia, 1990-92. Grana 36: 180-184.

- Imlay, J.A. and Linn, S. (1987): Mutagenesis and stress responses induced in Escherichia coli by hydrogen peroxide, J Bacteriol 169: 2967-2976.

- Imlay, J.A. and Linn, S. (1988): DNA damage and oxygen radical toxicity. Science 240: 1302-1309. 
- Jaroslave, D. and Millos, O. (1969): Mycological diagnosis of animal dermatophytosis. Academic publishing house of the Czechoslovak, Academy of Science, Prague.

- Jeffrey, J.S. (1997): Sanitation Disinfection Basics. Poultry fact no. 27. cooperative extension .University of California.

- Juven, B.J. and Pierson, M.D. (1996): Antibacterial effects of hydrogen peroxide and methods for its detection and quantization. $\mathbf{J}$ Food Prot 59(11):1233-41.

- Larsen, T.O. and Frisvad, J.C. (1994): Production of volatiles and mycotoxins in conidia of common Penicillia and Aspergilli. In: R.A. Samson and B. Flannigan, Editors, Health implications of fungi in indoor environments, Elsevier, Amsterdam pp. 251-279.

- Lund, A. and De Boer, D. J. (2008): Immunoprophylaxis of Dermatophytosis in Animals. Mycopathologia 166: 407-424.

- Luo, W. (1991): Deposition of large particles in the nose and mouth. Grana 30:79-81.

- Monica Cheesbrough, (1993): Medical laboratory manual for tropical countries. Vol. II. Microbiology and tropical health technology. Butterworth-Heinemann Ltd.

- Nooruddin, M. and Singh, B. (1987): Dermatophytosis in buffaloes, cattle and their attendants. Mykosen 30: 594-600

- Ovington, L.G.(2004): The truth about silver, Ostomy Wound Manage 50: $1 \mathrm{~S}-10 \mathrm{~S}$.

- Pepys, J. (1965): Hypersensitivity disease of the lung due to fungi and organic dusts., S. Karger, Basel . 
- Pier, A.C.; Smith, J.M.B.; Alexiou, H.; Ellis, D.H.; Lund, A. and Pritchard, R.C. (1994): Animal ringworm -its aetiology, public health significance and control. J Med Vet Mycol. 32(Suppl 1):133-50.

- Pitt, J.I. (1994): The current role of Aspergillus and Penicillium in human and animal health. J. Med. And Vet. Micology 32(S1):17-32.

- Radostits, O. M.; Blood, D. C. and Gay, C. C. (1997): Veterinary Medicine, $8^{\text {th }}$ Ed, Bailliere Tindall, London: 381-390

- Rebell, G. and Taplin, D. (1970): Dermatophyte. Their recognition and identification. $2^{\text {nd }}$ Ed. Coral Gables, Florida University and Miami press.

- Richards, R.M.E.(1981): Antimicrobial action of silver nitrate.Microbios. 31:83-91.

- Russell, A. D. (1991): Chemical sporicidal and sporostatic agents. In: Block SS., editor. Disinfection, sterilization, and preservation. 4th ed. Philadelphia, Pa: Lea \& Febiger. : 365-376.

- Rycroft, A.X. and Mclay, C. (1991): Disinfectants in the control of small animal ringworm due to Microsporum canis. Vet Rec. 129:239_ 41.

- Sarkisov, A. and Nikiforov, L. (1981): Specific prevention of trichophytosis in fur-bearing animals. Veterinaria Moscow, 7:37-38.

- Scott, D.W.; Miller, J.W.H. and Griffin, C.E. (1995): Dermatoses of pet rodents, rabbits and ferrets, in Muller and Kirk's Small Animal Dermatology (ed 5). Philadelphia, PA, W. B. Saunders: 112-1173. 
- Silver, S. (2003): Bacterial silver resistance: molecular biology and uses and misuses of silver compounds, FEMS Microbiol Rev 27:341353.

- Simaljakova Buchvald M. J. and Olexova, B. (1989): Microsporum cauls infection in rabbits and its transmission to humans. Mycoses 32:93-96.

- Stetzenbach, L.D. (1998): Microorganisms and indoor air quality. Clin. Microbiol. Newsl. 20: 157-161.

- Szilli,M.and Kohlami,I. (1981): Endemic Trichophyton mentagrophytes infection of rabbit origin, Mykosen, 24:412-420.

- Takahasi, T. (1997): Airborne fungal colony-forming units in outdoor and indoor environments in Yokohama, Japan. Mycopathologia 139: 23-33.

- Thurmann, R.B. and Gerba, C.P. (1988): Molecules mechanisms of viral inactivation by water disinfectants. Adv Appl Microbiol. 33:75105.

- Torres-Rodriguez, J.M.; Dronda, M.A.; Rosell, J. and Madrenys, N. (1992): Incidence of dermatophytosis in rabbit farms in Catalonia, Spain, and its repercussion on human health.Eur J.Epidemiol.8:326-9.

- Zaror, L. and Casas, S. (1988): [Microsporum canis in healthy angora rabbits (Valdix4a, Chile)]. Zentralbl Veterinarmed [B] 35:204-206. 